\title{
Histological Changes in Calcium Regulating Endocrine Gland (Ultimobranchial) After Dimethoate Exposure in Freshwater Catfish Heteropneustes Fossilis
}

\author{
Rakesh Kumar Pandey ${ }^{*}$ Vijai Krishna Das \\ Department of Zoology, Kamla Nehru Institute of Physical and Social Sciences, Sultanpur U.P., India \\ Email address: \\ rakeshzoology@gmail.com (R. K. Pandey),davkster@gmail.com (V. K. Das)
}

\section{To cite this article:}

Rakesh Kumar Pandey, Vijai Krishna Das. Histological Changes in Calcium Regulating Endocrine Gland (Ultimobranchial) After Dimethoate Exposure in Freshwater Catfish Heteropneustes Fossilis. American Journal of Bioscience and Bioengineering. Vol. 3, No. 5, 2015, pp. 91-98. doi: 10.11648/j.bio.20150305.22

\begin{abstract}
Ultimobranchial gland in fishes is associated primarily with calcium regulation. The study was aimed to find effect of an organophosphate pesticide dimethoate on serum $\mathrm{Ca}^{2+}$ and ultimobranchial gland in freshwater catfish Heteropneustes fossilis. Fish were exposed to dimethoate at $2.24 \mathrm{mg} / \mathrm{l}\left(75 \%\right.$ of $\left.96 \mathrm{~h} \mathrm{LC} \mathrm{L}_{50}\right)$ for short-term $(24,48,72 \mathrm{and} 96 \mathrm{~h})$, and $25 \%$ of $96 \mathrm{~h} \mathrm{LC}_{50}(1.00 \mathrm{mg} / \mathrm{l})$ for long-term $(6,12,24$ and $36 \mathrm{~d})$. The blood samples collected at assigned durations from the anaesthetized fish were used to measure serum $\mathrm{Ca}^{2+}$ levels. At the same time UBG were also extricated from the fish by removing the tissues adjoining esophagus, liver and sinus venosus of the heart for subsequent histological examination. A significant $(\mathrm{P}<0.05)$ increase in serum $\mathrm{Ca}^{2+}$ levels of fish following $24 \mathrm{~h}$ and $6 \mathrm{~d}$ dimethoate exposure was observed. However, after $48 \mathrm{~h}$ and $12 \mathrm{~d}$ the $\mathrm{Ca}^{2+}$ level gradually begins to decline exhibiting significant $(\mathrm{P}<0.0001)$ hypocalcaemia after $96 \mathrm{~h}$ and $36 \mathrm{~d}$ in the exposed fishes. The histological examination of exposed fish glands exhibit significant changes in their cellular activity, staining property, nuclear diameter and nuclear volume, vacuolization and degeneration. It is concluded that dimethoate severely hampers the calcium homeostasis in Heteropneustes fossilis; therefore the pesticide should be cautiously used near aquatic bodies.
\end{abstract}

Keywords: Ultimobranchial Gland, Dimethoate, Calcium, Heteropneustes fossilis

\section{Introduction}

In vertebrates, calcium plays vital roles in variety of biological functions - cell signaling, neural transmission, muscle contraction, blood coagulation, enzymatic co-factor, membrane and cytoskeletal functions, secretion, biomineralization, cell adhesion, acid-base balance, and initiation of many endocrine events. Serum and extracellular calcium concentrations in mammals are closely regulated within a narrow physiological range (between 2.25 and 2.75 $\mathrm{mM}$ ). Applications of pesticides in agricultural have increased tremendously in recent years and through rain water these pesticides reach aquatic bodies, inadvertently exposing fish and other organisms. Adverse effects of pesticide on fish have been studied by many workers $[1,2,3]$. The pesticides cause disruption in calcium regulating endocrine glands and other vital organs of the fish [1, 2, 3, 4, 5].
The Ultimobranchial gland (UBG) is one of the calcium regulating glands to develop in all jawed vertebrates. It develops embryologically from the epithelium of the last or "ultimate" branchial pouch. The response of UBG after calcitonin administration has been reported in fresh water teleost Cyprinus carpio [6] and Heteropneustes fossilis [7]. Environmental contaminants affect the activity of UBG and thus interfere with the $\mathrm{Ca}^{2+}$ homeostasis in the fish body. There are only limited reports on the effects of toxicants on the UBG under experimental condition $[8,9,10,11,12]$. Suzuki et al. [13] have reported that tributylin inhibits osteocalcin activity and disrupts calcium metabolism through an increase in plasma calcium and calcitonin levels in teleosts.

In present study, the histopathological alterations in the ultimobranchial glands of freshwater catfish Heteropneustes fossilis were investigated after dimethoate exposure. 


\section{Material and Method}

\subsection{Collection and Handling of Fish}

The adult fish comprising both sexes were collected from local ponds and carefully brought to the laboratory, avoiding any injury during transportation. Fish were treated with $0.05 \%$ $\mathrm{KMnO}_{4}$ solution for 2 minutes to remove any cutaneous infection. The fish after treatment were kept in plastic tank of $500 \mathrm{~L}$ capacity for 14 days to acclimatize under laboratory conditions. They were fed on alternate days with fish-food prepared from wheat flour mixed together with crushed soybean and mustard cake and dried prawn powder in ratio of $3: 1: 1: 1$. Food was given in the evening. The leftover food and water from the tank was removed and replenished with fresh water in the subsequent morning. Feeding was stopped $24 \mathrm{~h}$ prior to the toxicity test. Fish were exposed to natural photoperiods and were kept at room temperature. The physicochemical parameters such as dissolved oxygen (DO), temperature, $\mathrm{pH}$ and hardness $\left(\right.$ as $\mathrm{CaCO}_{3}$ ) of the test media were recorded daily according to the standard methods on water quality assessment provided by APHA [14].

\subsection{Experimental Procedure}

The experiments were carried out in glass aquaria of $15 \mathrm{~L}$ capacity in static laboratory conditions. The fish approximately of uniform length $(17.4 \pm 1.14 \mathrm{~cm})$ and weight $(27.14 \pm 1.95 \mathrm{~g})$ were selected for the bioassay. Fish were not given any food during the experiment.

After determining the $\mathrm{LC}_{50}$ values, fish were exposed to dimethoate for biochemical examinations of serum electrolytes levels and histopathological study of endocrine glands. The fish were subjected to sub-lethal concentration of dimethoate $2.24 \mathrm{mg} / 1$ ( $75 \%$ of $96 \mathrm{~h} \mathrm{LC}_{50}$ ) for short term (24, $48,72$ and $96 \mathrm{~h})$, and $25 \%$ of $96 \mathrm{~h} \mathrm{LC}_{50}(1.00 \mathrm{mg} / \mathrm{l})$ for long term $(6,12,24$ and $36 \mathrm{~d})$ exposure. A set of control was run concurrently. Ten fishes from each duration (exposed and

control) were randomly selected and anaesthetized with $0.03 \%$ MS-222 (tricaine methane sulfonate), and blotted with dry absorbent paper for collection of blood. The blood samples collected in citrated tuberculin syringe directly from the bulbus arteriosus were used to measure serum $\mathrm{Ca}^{2+}$ levels. Serum $\mathrm{Ca}^{2+}$ levels were measured using Erba Mannheim diagnostic kit (Erba Diagnostics Mannheim $\mathrm{GmbH}$, Germany).

\subsection{Histological Procedure}

For histological examination of the UBG, the tissues from the oesophageal region adjoining the heart (sinus venosus) and connective tissue together with a portion of liver were removed and fixed in Bouin's fluid. After routine dehydration and embedding in paraffin wax serial sections were cut at 5-6 $\mu \mathrm{m}$, stained in Haematoxylin - Eosin and mounted in DPX.

\subsection{Determination of Nuclear Volume}

To determine the average nuclear diameter of the gland cells, 50 nuclei were randomly selected from every fourth section of the gland and their diameter was measured with the help of oculometer under oil immersion (x1000). In total over 200 nuclei were always measured for each gland. The nuclear volume (NV) was calculated by the formula-

$$
\mathrm{NV}=4 / 3 \pi \mathrm{a} \cdot \mathrm{b}^{2}
$$

(Where, ' $a$ ' is the major nuclear axis and ' $b$ ' represents the minor nuclear axis).

\section{Statistical analysis}

Student's t-test was used to analyze the statistical significance between control and dimethoate exposed fish. All data were presented as mean $\pm \mathrm{SD}$ of ten specimens and values at $\mathrm{P}<0.05$ were accepted as significant.

\section{Results}

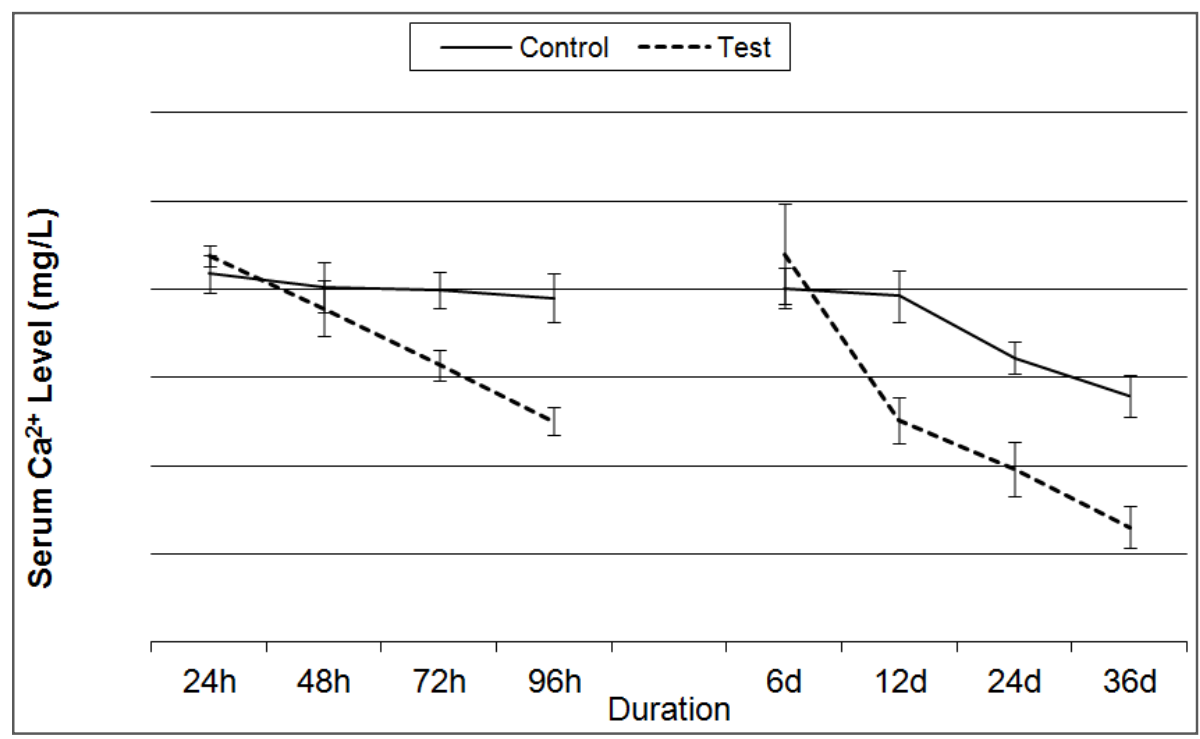

Fig. 1. Serum Ca2+ level in Heteropneustes fossilis after short term (75\% of $\left.96 \mathrm{~h} \mathrm{LC50}=2.24 \mathrm{mg} \mathrm{L}^{-1}\right)$ and long term $\left(25 \%\right.$ of $\left.96 \mathrm{~h} \mathrm{LC50}=0.75 \mathrm{mg} \mathrm{L} \mathrm{L}^{-1}\right)$ dimethoate exposure. Values are given as Mean $\pm S D, n=10$ (Students 't-test). 


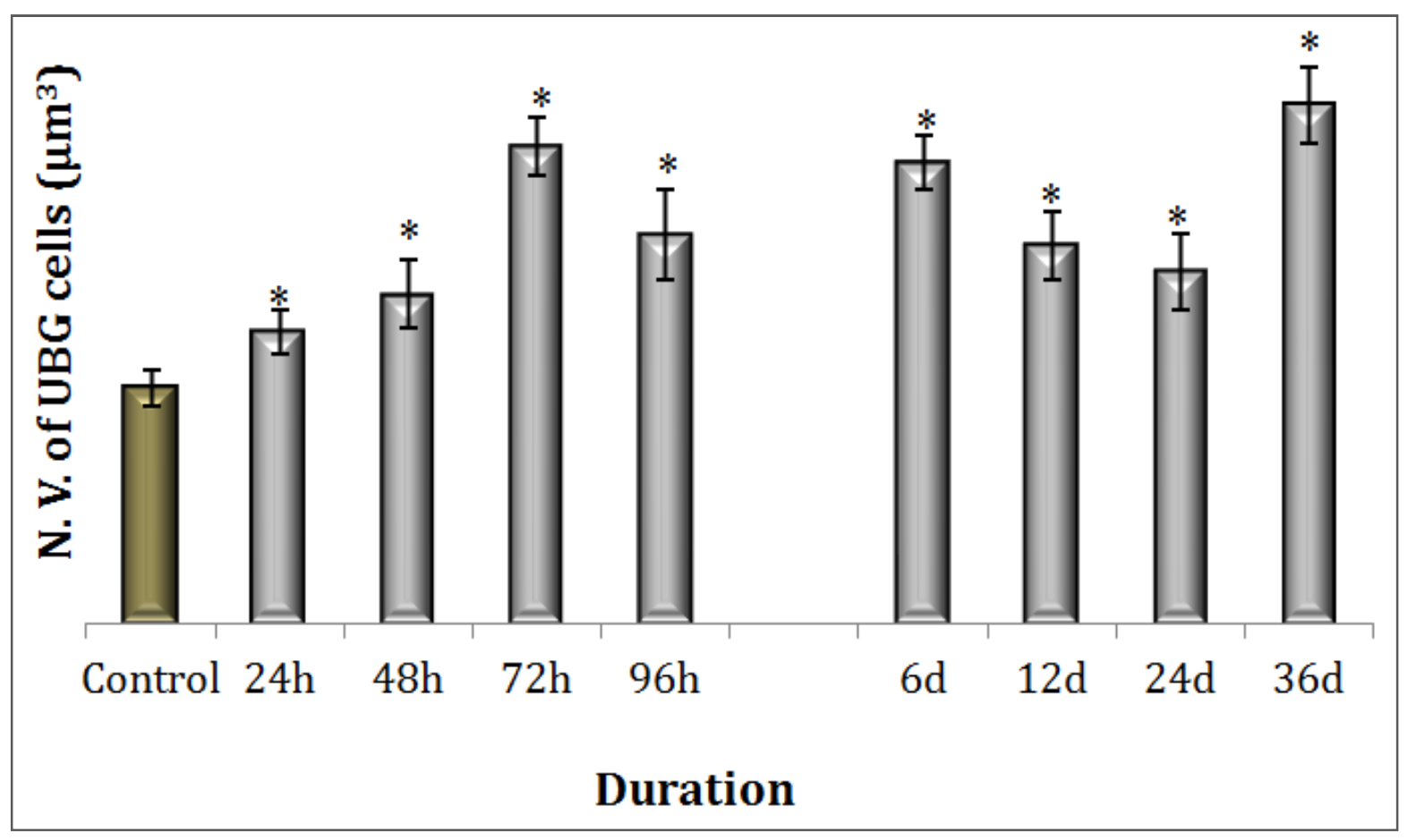

* Significant $(\mathrm{P}<0.05$, Student's t-test $)$

Fig. 2. Nuclear Volume (NV) of UBG cells after dimethoate exposure in Heteropneustes fossilis.

The freshwater catfish Heteropneustes fossilis, exposed to sub-lethal concentration of dimethoate $\left(75 \%\right.$ of $96 \mathrm{~h} \mathrm{LC}_{50}=$ $2.24 \mathrm{mg} / \mathrm{l})$ for the short-term $(96 \mathrm{~h})$ experiment recorded significant $(\mathrm{P}<0.05)$ increase in serum $\mathrm{Ca}^{2+}$ levels following $24 \mathrm{~h}$ dimethoate exposure. The calcium levels, however, showed a decline after $48 \mathrm{~h}$ and continued to fall gradually up to $96 \mathrm{~h}$, exhibiting significant $(\mathrm{P}<0.0001)$ hypocalcaemia in the exposed fishes (Fig.1). In long-term dimethoate exposure $\left(1.00 \mathrm{mg} / \mathrm{l}=25 \%\right.$ of $\left.96 \mathrm{~h} \mathrm{LC}_{50}\right)$, the serum $\mathrm{Ca}^{2+}$ level recorded a minor increase after 6 days (Fig. 1), thereafter, exhibited a gradual decrease, leading to significant hypocalcaemia up to $36 \mathrm{~d}(\mathrm{P}<0.0001)$.

The morphometric examination of ultimobranchial glands of pesticide exposed fish exhibit changes in their cellular activity, staining property, nuclear diameter and nuclear volume, vacuolization and degeneration (Fig 2-12).

The UBG in Heteropneustes fossilis are present on the abdominal surface of the oesophagus and spread on the septum separating pericardium and viscera. It is located around the oesophageal wall (Fig. 3, 4). The gland comprises a solid parenchymal tissue formed of compactly arranged cell cords which sometimes enclose a lumen or follicle with few disintegrating cells. The cell cords are lined by a thin basement membrane. The cells exhibit differential staining capacity: a large population of darkly stained cells and lesser number of light stained cells (Fig. 4).

In short-term dimethoate exposure the glandular cells of UBG exhibit hypertrophy and an increase in the population of lightly stained cells, after $24 \mathrm{~h}$ of treatment (Fig. 5). Following $48 \mathrm{~h}$ the UBG exhibits cellular hypertrophy and hyperplasia and dilation of blood capillaries. The population of lightly stained cells is increased as compared to darkly stained cells and the cells show vacuolization and nuclear pycnosis (Fig. 6). After $72 \mathrm{~h}$ the nuclei of the glandular cells exhibit further hypertrophy. The cell cords can be recognized by showing shrinkage, appearance of lumen and invasion of connective tissue in between the cords. There is reappearance of darkly stained cells in the gland and blood vessels exhibit further dilation (Fig. 7). The UBG of $96 \mathrm{~h}$ exposed fish exhibits reduction in nuclear volume (Fig. 2). There is cellular hyperplasia associated with severe vacuolization leading to follicular degeneration at places. The number and staining capacity of darkly stained cells has increased (Fig. 8).

In long-term experiment, the UBG exhibits nuclear hypertrophy and abundance of light staining cells and increased dilation of blood vessels show after $6 \mathrm{~d}$ exposure to dimethoate (Fig. 9). Following $12 \mathrm{~d}$ dimethoate treatment the cytoarchitecture of the UBG cell cords is disrupted and there is reappearance of dark staining cells. The light stained cells undergo disintegration and finally collapse in dark masses of cellular debris due to which the nuclear volume records a minor decrease (Fig. 10). After $24 \mathrm{~d}$ exposure the gland reorganizes and exhibits a large population of darkly stained nuclei and the nuclear volume undergoes further reduction. The gland shows vacuolization and dilation of blood capillaries. The central portion of the gland shows complete disintegration and collapse of cells (Fig. 11).The ultimobranchial cell cords following $36 \mathrm{~d}$ exposure exhibit complete collapse and disintegration. It is very difficult to recognize the cell and measure the nuclear volume. At places where the size of nuclei could be measured, exhibited hypertrophy. The blood vessels show dilation (Fig. 12). 


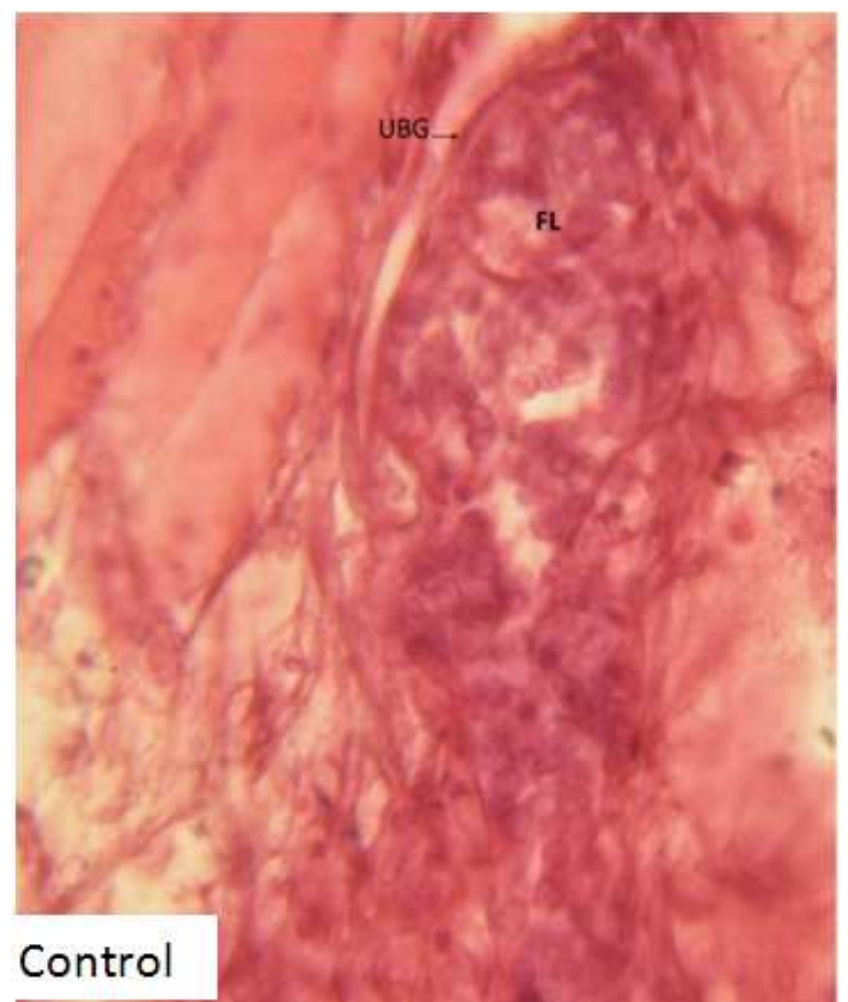

Fig. 3. UBG of Heteropneustes fossilis located around the oesophageal wall (OE) bellow the septum (SE). [Haematoxylin - Eosin, X400].

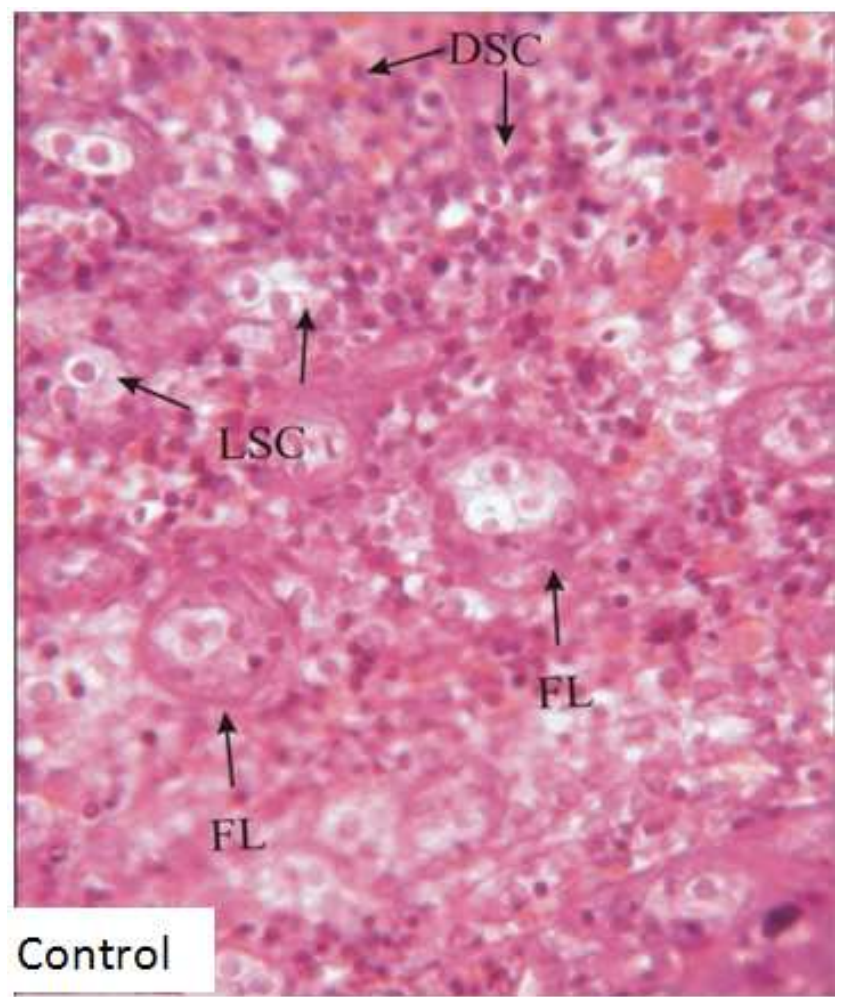

Fig. 4. UBG of untreated control fish comprises solid parenchymal tissue formed of compactly arranged cell cords sometimes enclosing a lumen (FL) with few disintegrating cells. The cells exhibit differential staining capacity: large population of darkly stained cells (DSC) and lesser number of light stained cells (LSC). [Haematoxylin - Eosin, X1000]

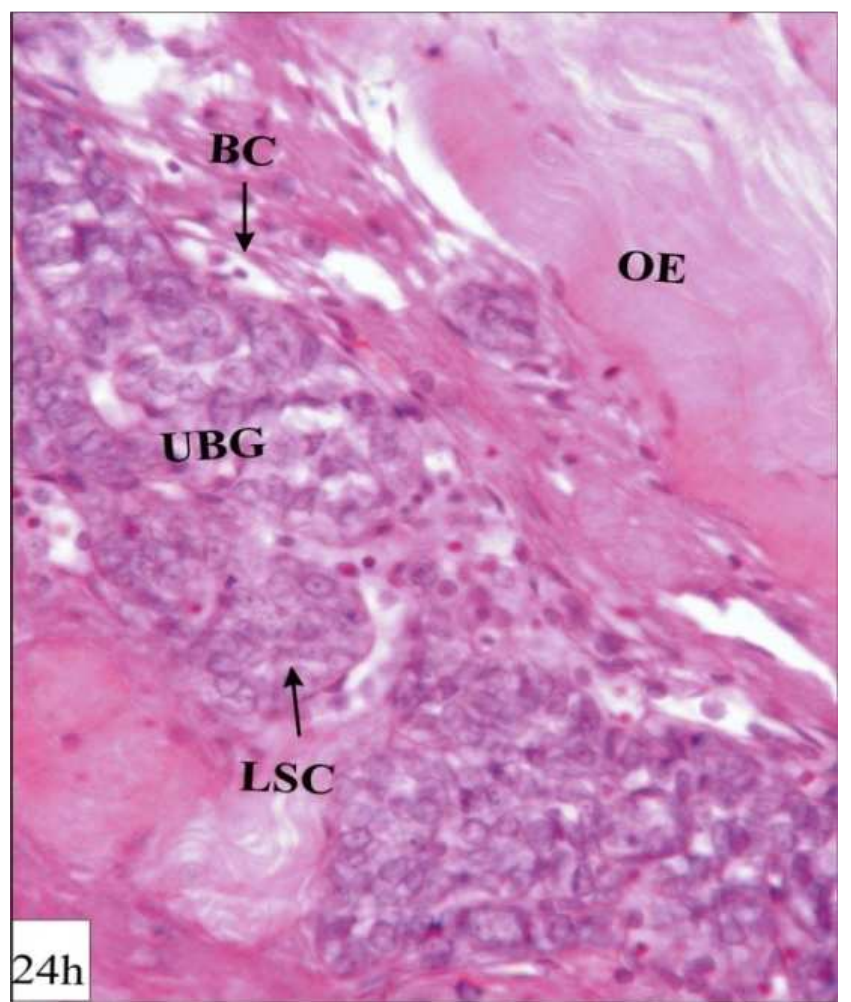

Fig. 5. $24 h$ dimethoate treated $U B G$ showing glandular hypertrophy; increased population of light stained cells LSC and dilation of blood capillaries (BC). [Haematoxylin - Eosin, X1000].

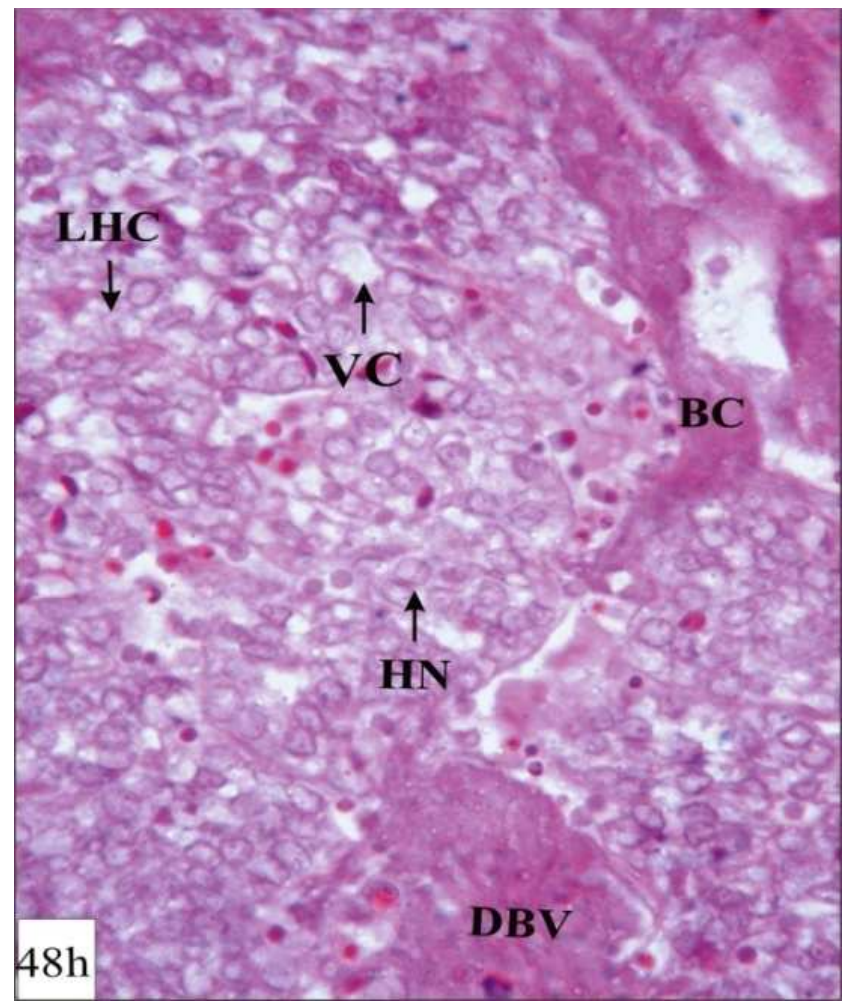

Fig. 6. 48 h dimethoate treated UBG exhibiting hypertrophic nuclei $(H N)$; increased population of light stained cells (LSC); vacuolization (VC), nuclear pycnosis and dilated blood vessels (DBV). [Haematoxylin - Eosin, X1000]. 


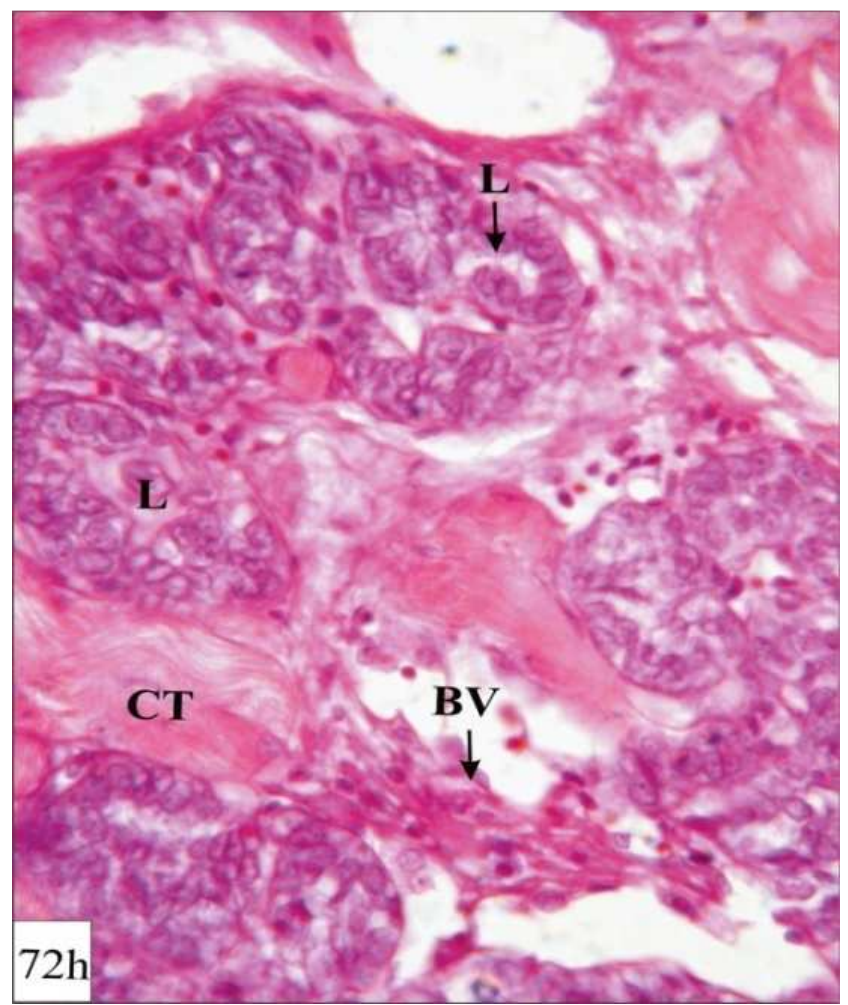

Fig. 7.72 h dimethoate treated UBG exhibiting hypertrophy (H); cells cord showing shrinkage and appearance of lumen $(L)$; invasion of connective tissues (CT) between the cords; reappearance of dark staining cells (DSC) and further dilation of blood vessels (BV). [Haematoxylin - Eosin, X1000].

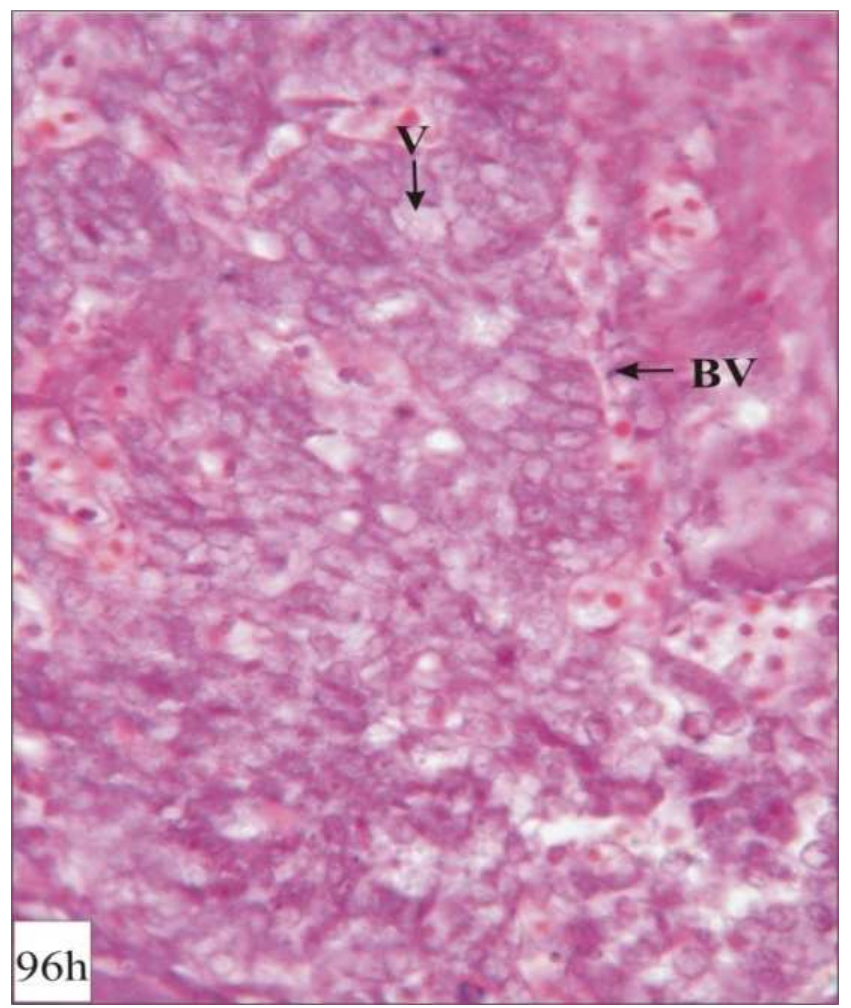

Fig. 8. 96 h dimethoate treated UBG exhibiting cellular hyperplasia with severe vacuolization (V); follicular degeneration (FD) at some places and increased staining capacity of the cells in the cord. [Haematoxylin-Eosin, X1000].

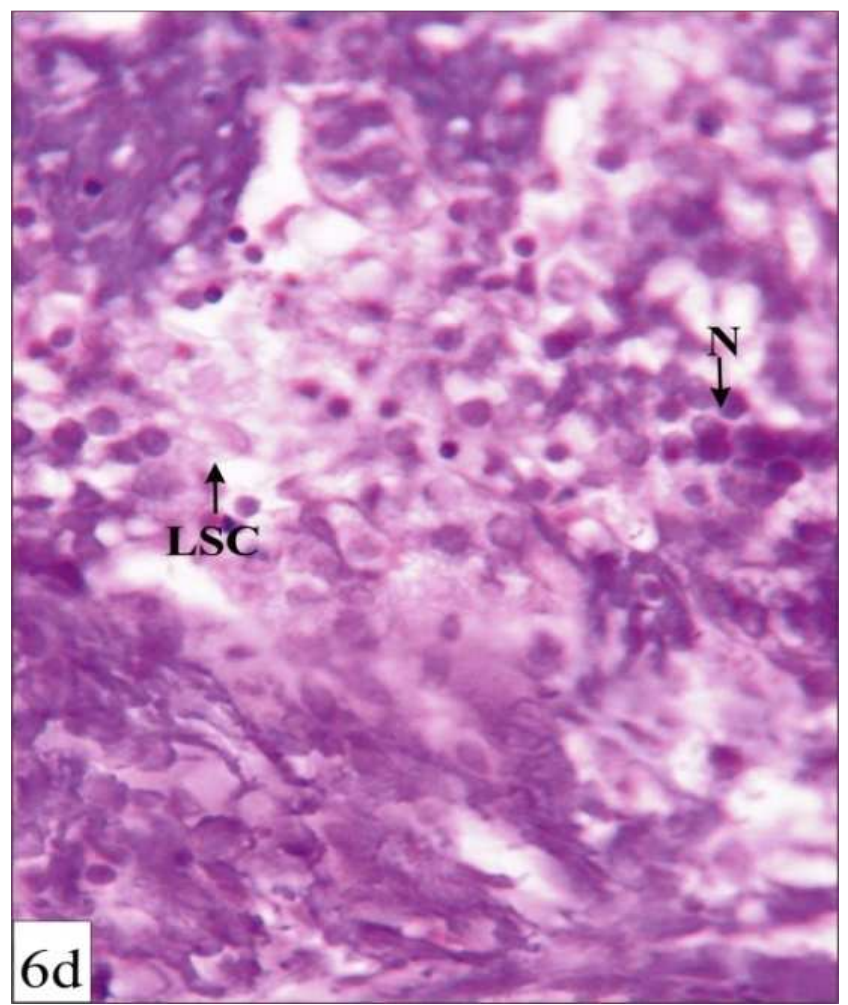

Fig. 9. 6 d dimethoate treatedUBG cell showing nuclear hypertrophy (N) and abundance of (light stained cells). LSC [Haematoxylin - Eosin, X1000].

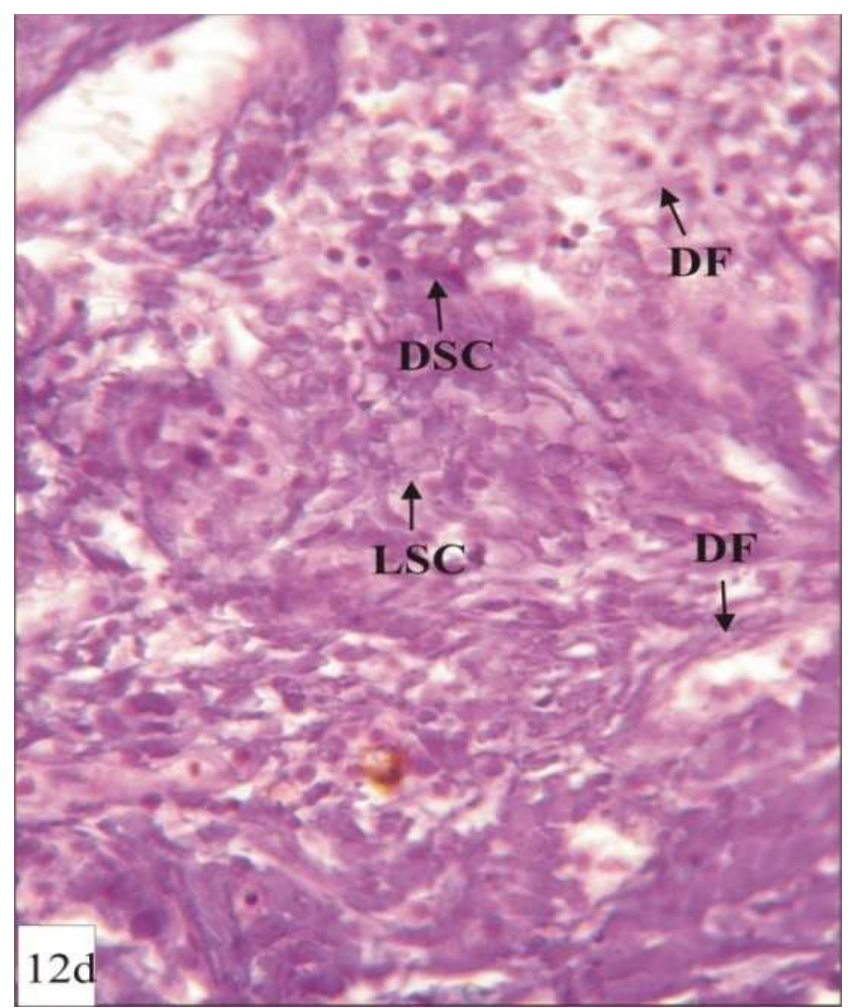

Fig. 10. 12 d dimethoate treatedUBG showing disruption in cytoarchitecture of cell cords; reappearance of dark staining cell (DSC), and disintegration of light staining cells (LSC). [Haematoxylin - Eosin, X1000]. 


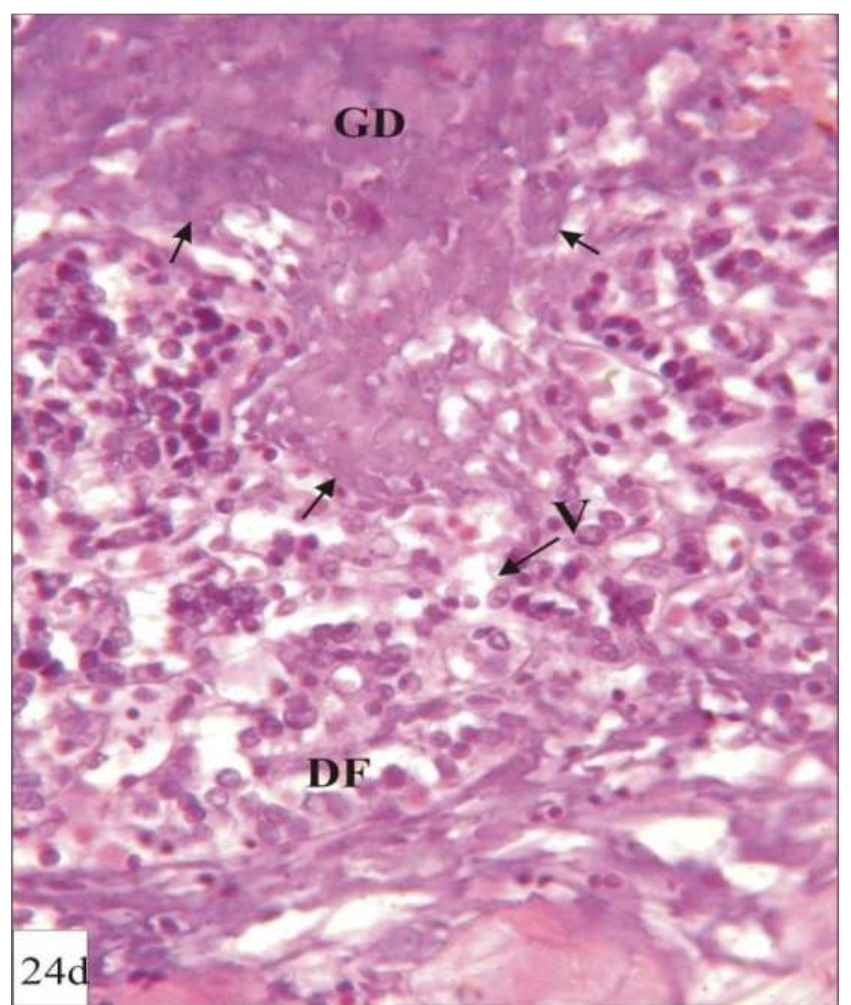

Fig. 11. 24 d dimethoate treated UBG exhibiting a large population of darkly staining (DSC); vacuolization (V); glandular degeneration (GD); invasion of connective tissue (CT); dilated blood capillaries. The central portion of the gland showing complete disintegration (arrows) and collapsed cell mass (CM). [Haematoxylin - Eosin, X1000].

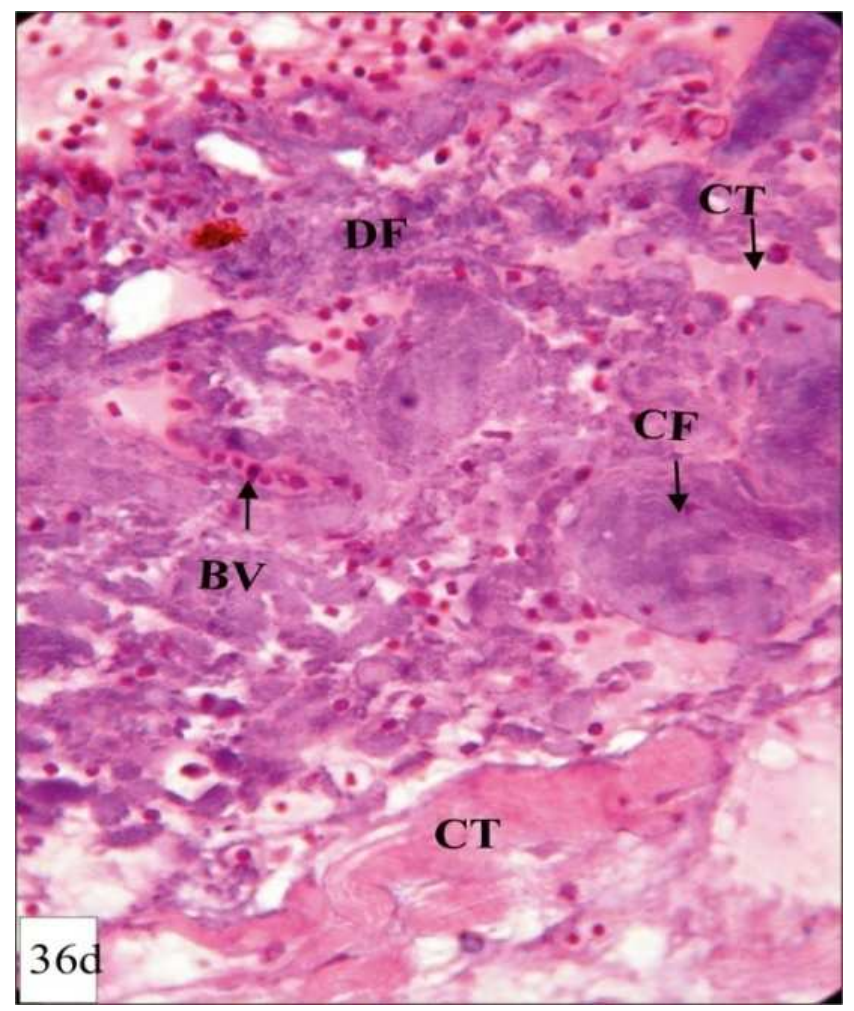

Fig. 12. $36 d$ dimethoate treated $U B G$ exhibiting complete collapse (CF) and disintegration; cells difficult to be recognized and highly dilated blood vessels (BV). [Haematoxylin - Eosin, X1000].

\section{Discussion}

Dimethoate exposure induces hypocalcemia, hyperphosphatemia and hypermagnesemia after short term $\left(75 \%\right.$ of $\left.96 \mathrm{~h} \mathrm{LC}_{50}=2.24 \mathrm{mg} / \mathrm{l}\right)$ and long term $(25 \%$ of $96 \mathrm{~h}$ $\left.\mathrm{LC}_{50}=1.00 \mathrm{mg} / \mathrm{l}\right)$ treatment in Heteropneustes fossilis. Initial increase (at $24 \mathrm{~h}$ and $6 \mathrm{~d}$ ) in calcium level (Fig. 1) may be due to mobilization of calcium from its storage depots (bones and muscles) in order to maintain $\mathrm{Ca}^{2+}$ homeostasis and to support certain physiological activities [15]. The decline in calcium over time (Fig. 1) may be an indication of exhaustion of the $\mathrm{Ca}^{2+}$ depots and its reduced uptake from gills and kidney tissues due damage induced by the pesticide $[16,17,18,19,20]$. Hypocalcemia exhibited by the fish during short term and long term exposure to dimethoate in this study is similar to the observations made by earlier workers with aldrin [21] and also with propoxur and formothion [22]. Hypocalcemia and hypophosphatemia have also been observed in teleosts exposed to cypermethrin, deltamethrin, metacid-50, chlorpyrifos pesticides $[1,10,23$, 24, 25]. Velisek et al. [26] have reported no significant change in $\mathrm{Ca}^{2+}$ and Pi levels in common carp when exposed to deltamethrin, however, a decline in serum $\mathrm{Ca}^{2+}$ levels in a freshwater teleost, Sarotherodon mossambicus when exposed to dimecron was recorded [27]. Recently, Prasad et al. observed a progressive decrease in serum calcium level in Heteropneustes fossilis after $48 \mathrm{~h}$ (short term) and $7 \mathrm{~d}$ (long term) exposure to E. royleana latex which persisted until the end of the experiments [28]. Endosulfan induces an increase in the level of serum prolactin in fish Sarotherodon mossambicus [29]. Damage in gill epithelium inhibits $\mathrm{Ca}^{2+}$ uptake from the surrounding water resulting into hypocalcemia and respiratory distress together with hyperexitability and body tremor in Heteropneustes fossilis $[1,2]$.

After short term exposure fish to sub-lethal concentration of dimethoate $2.24 \mathrm{mg} / 1$ ( $75 \%$ of $\left.96 \mathrm{~h} \mathrm{LC}_{50}\right)$, the UBG shows signs of hyperactivity (hypertrophy and increased NV) up to 72 h (Fig. 2-7). Thereafter, the gland exhibits degenerative signs such as decline in NV and severe vacuolization (Fig. 2, $8)$. In long term exposure of dimethoate $\left(25 \%\right.$ of $96 \mathrm{~h} \mathrm{LC}_{50}$ $=1.00 \mathrm{mg} / \mathrm{l})$, the UBG gland also undergo hyperactivity after $6 \mathrm{~d}$ (increased NV) thereafter the gland exhibits signs of degeneration (the cell cords are disrupted and light stained cells collapse in dark mass of cellular debris) and ultimately the gland disintegrates ((Fig. 9-12). There are reports which confirm our observations that pesticides affect the activity the UBG and cause damage to the gland. Srivastav et al. reported no change in the UBG of Heteropneustes fossilis up to $72 \mathrm{~h}$ and $14 \mathrm{~d}$ exposure to deltamethrin [8]. However, they reported reduced activity (reduced staining response, decrease in NV, degeneration and vacuolization) of UBG only after $96 \mathrm{~h}$ and $28 \mathrm{~d}$ of exposure. Similar observations have been made in the UBG hypo-activity of Heteropneustes fossilis exposed to cypermethrin [10] and cadmium [11] for short-term and long-term durations. UBG of chlorpyrifos treated fish exhibits no histological change up to $48 \mathrm{~h}$ (short 
term) and $14 \mathrm{~d}$ (long term) but after $72 \mathrm{~h}$ and $21 \mathrm{~d}$ of chlorpyrifos exposure, the gland exhibits signs of degeneration (reduced staining and decreased NV) which become exaggerated after $96 \mathrm{~h}$ and after $28 \mathrm{~d}$ with vacuolization and degeneration [9]. The calcitonin of ultimobranchial gland of fish is well known for its hypocalcemic or anti-hypercalcemic action [30,31]. The initial hypercalcemia observed in the present study induces the UBG to secrete more calcitonin and due to which the UBG remains continuously active and gradually becomes exhausted showing collapse of the gland.

\section{Conclusion}

Pesticide induced physiological stress manifests in the form of biochemical alterations. It may be concluded from the present study that dimethoate is highly toxic to fish Heteropneustes fossilis and adversely damages the homeostatic balance of body electrolytes, especially $\mathrm{Ca}^{2+}$ and severely affect endocrine glands. Histological damage in ultimobranchial gland results in altered $\mathrm{Ca}^{2+}$ regulation after prolonged exposure.

\section{Acknowledgements}

Authors are thankful to the Principal, Kamla Nehru Institute of Physical and Social Sciences, Sultanpur, for providing required research facilities.

\section{References}

[1] Pandey RK, Malviya A and Das VK: Toxicity of cypermethrin, effects on serum electrolytes $\left(\mathrm{Ca}^{+2}, \mathrm{Mg}^{+2}\right.$ and $\left.\mathrm{Pi}\right)$ levels and recovery response in fresh water catfish Heteropneustes fossilis (Bloch). Int. J. Biol. Chem. Sci. 3 (5): 1182-1191, 2009a.

[2] Pandey RK, Singh RN, Singh S, Singh NN and Das VK: Acute toxicity bioassay of dimethoate on freshwater air breathing catfish, Heteropneustes fossilis (Bloch) and its behavioural studies. J. Environ. Biol. 30 (3): 437-440, 2009 b.

[3] Mishra D, Srivastav SK, Suzuki N and Srivastav AK: Corpuscles of Stannius of a teleost Heteropneustes fossilis following intoxication with a pyrethroid (Cypermethrin). North-Western J. Zool. 6 (2): 203-208, 2010.

[4] Das VK, Malviya A and Pandey RK: Alterations in serum electrolytes (calcium, magnesium and phosphate) levels after dimethoate exposure and pesticide withdrawal recovery in the freshwater air-breathing catfish Heteropneustes fossilis (Bloch): Toxicol. Environ .Chem. 95(7): 1176-1182, 2013.

[5] Pandey RK and Das VK: Dimethoate induced changes in serum $\mathrm{Ca}^{2+}$ and Corpuscles of Stannius in freshwater catfish Heteropneustes fossilis, after short-term and long-term exposure. Am. J. Life Sci. 3(1): 17-21, 2015.

[6] Chakrabarti P and Mukherjee D: Studies on the hypocalcemic actions of salmon calcitonin and ultimobranchial gland extracts in the freshwater teleost, Cyprinus carpio. Gen. Comp. Endocrinol. 90: 267-273, 1993.
[7] Srivastav AK, Singh S, Mishra D and Srivastav SK: Ultimobranchial gland of freshwater catfish, Heteropneustes fossilis, in response to calcitonin administration. Pesq. Vet. Bras. 29 (12): 963-968, 2009.

[8] Srivastav AK, Srivastava SK, Mishra D, Srivastav S, Srivastav SK: Ultimobranchial gland of freshwater catfish, Heteropneustes fossilis in response to deltamethrin treatment. Bull. Environ. Contam. Toxicol. 68 (4): 584-591, 2002.

[9] Srivastav AK, Srivastava SK, Mishra D, Srivastav SK: Histological alterations in the ultimobranchial gland of teleost Heteropneustes fossilis in response to chlorpyrifos treatment. J.Basic Clin. Physiol. Pharmacol. 22 (1-2): 23-28, 2011.

[10] Mishra D, Srivastav SK and Srivastav AK: Effects of the insecticide cypermethrin on plasma calcium and ultimobranchial gland of a teleost, Heteropneustes fossilis. Ecotoxicol. Environ. Saf. 60 (2): 193-197, 2005.

[11] Rai R, Mishra D,Srivastav SKand Srivastav AK: Ultimobranchial gland of a freshwater teleost, Heteropneustes fossilis, in response to cadmium treatment. Environ. Toxicol. 24 (6): 589-593, 2009.

[12] Kumar A, Prasad MR, Suzuki N, Srivastava SK and Srivastava AK: Influence of a botanocal pesticide, azadirachtin, on ultimobranchial gland of the freshwater catfish Heteropneustes fossilis. Toxicol. Environ. Chem. 95 (10): 2013.

[13] Suzuki N, Tabata MJ, Kambegawa A, Srivastav AK, Shimada A, Takeda H, Kobayashi M, Wada S and Catsumata T: Tributylin inhibits osteoblastic activity and disrupts calcium metabolism through an increase in plasma calcium and calcitonin levels in teleosts. Life Sci. 78 (21): 2533-25410, 2006.

[14] APHA: Standard Methods for the Examination of Water and Wastewater, (21st Edn.), 2005. APHA, AWWA, WPCF: Washington DC, USA.

[15] Swarup K and Norman AW: Depletion of Ca and Pi in scales, bones and muscles associated with vitamin $\mathrm{D}_{3}$ induced hypercalcemia and hyperphosphatemia in Cyprinus carpio. Proc. Natl. Acad. Sci. India. 66: 243-252, 1996.

[16] Cengiz EI, and Unlu E: Sublethal effect of commercial Deltamethrin on the structure of the gills, liver and gut tissues of mosquito fish Gambusia affinis: a microscopic study. Environ. Toxicol. Pharm. 21: 246-253, 2006.

[17] Yildirim MZ, Benli AC, Selvi M, Ozkul A, Erkoc F and Kocak O: Acute toxicity, behavioral changes, and histopathological effects of deltamethrin on tissues (gills, liver, brain, spleen, kidney, muscle, skin) of Nile tilapia (Oreochromis nilkoticus L.) fingerlings. Environ. Toxicol. 21: 614-620, 2006.

[18] Velmurugan B, Selvanayagam M, Cengiz EI, Unlu E: The effects of monocrotophos to different tissues of freshwater fish Cirrhinus mrigala. Bull. Environ. Contam. Toxicol. 78: 450454, 2007.

[19] Peebua P, Kruatrachue M, Pokethitiyook P and Singhakaew S: Histopathological alterations of Nile tilapia, Oreochromis niloticus in acute and subchronic alachlor exposure. J. Environ. Biol. 29 (3): 325-331, 2008. 
[20] Parikh PH, Rangrez A, Bagchi RA and Desai BN: Effect of dimethoate on some histoarchitecture of freshwater fish Oreocromis mossambicus (Peters, 1852). Bioscan. 5: 55-58, 2010.

[21] Singh NN, VK Das and Singh S: Effect of aldrin on carbohydrate, protein and ionic metabolism of a freshwater catfish, Heteropneustes fossilis. Bull. Environ. Contam. Toxicol. 57: 204-210, 1996.

[22] Singh NN, Das VK and Srivastav AK: Formothion and propoxur induced ionic imbalance and skeletal deformity in a catfish, Heteropneustes fossilis. J. Environ. Biol. 18: 357-363, 1997.

[23] Mishra D, Srivastav S, Srivastav SK and Srivastav AK: Plasma calcium and inorganic phosphate levels of a freshwater catfish Heteropneustes fossilis in response to Cypermethrin treatment. J. Ecophysiol. Occup. Hlth. 1: 131138, 2001.

[24] Mishra D, Srivastav SK and Srivastav AK: Plasma calcium and inorganic phosphate levels of a teleost, Heteropneustes fossilis exposed to metacid-50. Malaysian App. Biol. 33: 1925, 2004.

[25] Logaswamy S, Radha G, Subhashini S and Logankumar K: Alterations in the levels of ions in blood and liver of freshwater fish, Cyprinus carpio var. communis exposed to dimethoate. Environ. Monit. Assess. 131: 439-444, 2007.
[26] Velisek J, Dobsikova R, Svobodova Z, Modra H and Luskova $\mathrm{V}$ : Effect of deltamethrin on the biochemical profile of common carp (Cyprinus carpio L.). Bull. Environ. Contam. Toxicol. 76: 992-998, 2006.

[27] Thangavel P, Sumathiral K, Karthikeyan S and Ramaswamy M: Endocrine response of the freshwater teleost, Sarotherodon mossambicus (Peters) to dimecron exposure. Chemosphere. 61: 1083-1092, 2005.

[28] Prasad MR, Kumar A, Mishra D, Srivastav SK and Srivastav AK: Blood electrolytes of the freshwater catfish Heteropneustes fossilis in response to treatment with a botanical pesticide (latex of Euphorbia royleana). Integrat. Zool. 6 (2): 150-156, 2011.

[29] Thangavel P, Sumathiral K, Maheswari S, Rita S and Ramaswamy M: Hormone profile of an edible, freshwater teleost, Sarotherodon mossambicus (Peters) under endosulfan toxicity. Pestic. Biochem. Physiol. 97: 229-234, 2010.

[30] Wendelaar Bonga, SE: Effect of synthetic salman calcitonin on plasma calcium, ultimobranchial cells, Stannius bodies and prolactin cells in the teleost Gasterosteus aculeatus. Gen. Comp. Endocrinol. 40: 99-108, 1980.

[31] Srivastav SP, Swarup K, Singh S and Srivastav AK: Effects of calcitonin administration on ultimobranchial gland, Stannius corpuscles and prolactin cells in male catfish, Clarias batrachus. Arch. Biol. 100: 385-392, 1989. 